\title{
Application of Herbal Meatball Product Processing Technology to Increase Stamina Against Covid 19 for the Wua Wua Subdistrict, Kendari City
}

\author{
H. Hafid ${ }^{1}$, Nuraini ${ }^{1}$, N.S. Asminaya ${ }^{1}$, R. Aka ${ }^{1}$, Fitrianingsih ${ }^{1}$, R.D.S. Toba ${ }^{1}$, \\ A.B. Kimestri ${ }^{1}$, S. H. Ananda ${ }^{2}$ \\ ${ }^{1}$ Animal Science Departement, Faculty of Animal Science, Halu Oleo University, Kendari, Indonesia \\ ${ }^{2}$ Nutrition Study Program, STIKES Karya Kesehatan, Kampus Anduonohu, Kendari, Indonesia
}

\begin{abstract}
One of the preventive efforts to protect yourself from the Covid 19 outbreak is to consume nutritious food ingredients. This training taught the community to make meatballs with added Moringa leaves so that it would be more nutritious. The method used in the first community service program is to approach, interview and deepen problems and find solutions to problems. Second, using the method of learning by doing with teaching media in the form of a guide book on how to make herbal meatballs, giving brochures and demonstrations and banners that attract the interest of the community. Providing counseling and training by providing training and demonstration material or practice how to make herbal meatballs. The results of the activity were the introduction of the knowledge and skills of the training participants, consisting of women members of the PKK who were very enthusiastic about participating in the training, who were also very active in participating in discussions and training demonstrations of making herbal products. This condition indicates that the community, especially housewives as members of the PKK, still really need guidance and counseling related to new things that are useful in everyday life, such as training materials for making herbal meatballs. This is due to limited access to the outside world because they are busy taking care of the household. Besides that, the training participants have a strong desire to turn herbal meatball products into an entrepreneurial field considering that meatballs are a type of culinary that is very popular with the community regardless of age and social status. It is hoped that this entrepreneurial interest can be realized so that it becomes an additional source of income for the participants. It was concluded that community service activities regarding the application of herbal meatball processing technology to improve tubular stamina during the pandemic covid 19 period had provided additional knowledge and skills to the people of Wua-Wua Subdistrict, Kendari City. The community
\end{abstract}

*Corresponding author at: Jl. HEA Mokodompit Kampus Bumi Tridarma Anduonohu

E-mail address: harapin.hafid@uho.ac.id

Copyright $@ 2018$ Published by Talenta Publisher, ISSN: 2621-4830

Journal Homepage: https://talenta.usu.ac.id/jst 
participating in the activity has applied herbal meatball processing technology to increase stamina against the covid pandemic 19 because the raw material of Moringa leaves is widely planted by the people of Kendari as a type of staple vegetable.

Keywords: Processing, Meatballs, Herbs, Moringa leaves, Immunity, Covid 19

Abstrak. Abstrak. Salah satu upaya preventif untuk menjaga diri dari wabah Covid 19 adalah dengan mengkonsumsi bahan makanan bergizi. Pelatihan ini mengajarkan masyarakat membuat bakso yang ditambahkan herbal daun kelor sehingga akan lebih bergizi. Metode yang dilakukan dalam program pengabdian masyarakat yang pertama adalah pendekatan, wawancara dan pendalaman permasalahan dan mencari solusi permasalahan. Kedua menggunakan metode learning by doing dengan media ajar berupa buku panduan cara membuat bakso herbal, pemberian brosur dan peragaan serta banner yang menarik minat masyarakat. Memberi penyuluhan dan pelatihan dengan memberi materi pelatihan dan peragaan atau praktek cara pembuatan bakso herbal. Hasil kegiatan berupa introduksi pengetahuan dan keterampilan peserta pelatihan yang terdiri dari ibu-ibu anggota PKK yang sangat antusias mengikuti pelatihan, juga sangat aktif berpartisipasi dalam diskusi dan demonstrasi pelatihan pembuatan produk herbal. Kondisi ini mengindikasikan bahwa bahwa masyarakat khususnya ibu-ibu rumah tangga sebagai anggota PKK masih sangat membutuhkan bimbingan dan penyuluhan terkait hal-hal baru yang bermanfaat dalam kehidupan sehari-hari seperti materi pelatihan pembuatan bakso herbal. Hal ini disebabkan terbatasnya akses dunia luar karena kesibukan mereka mengurus rumah tangga. Disamping itu besar keinginan peserta pelatihan untuk menjadikan produk bakso herbal menjadi lapangan wirausaha mengingat bakso merupakan salah satu jenis kuliner yang sangat digemari masyarakat tanpa mengenal batas usia dan status sosial. Minat wirausaha ini diharapkan dapat diwujudkan agar menjadi sumber tambahan pendapatan para peserta. Disimpulkan bahwa kegiatan pengabdian masyarakat tentang penerapan teknologi pengolahan bakso herbal untuk memperbaiki stamina tubuh di masa pandemi covid 19 telah memberikan tambahan pengetahuan dan keterampilan kepada masyarakat Kecamatan Wua Wua Kota Kendari. Masyarakat peserta kegiatan telah menerapkan teknologi pengolahan bakso herbal untuk meningkatkan stamina melawan pandemic covid 19 sebab bahan baku daun kelor banyak ditanam masyarakat Kendari sebagai salah satu jenis sayuran pokok.

Kata Kunci: Teknologi pengolahan, Bakso, Herbal, Daun kelor, Imunitas, Covid 19 Received 10 July 2020| Revised 28 August 2020| Accepted 20 September 2020

\section{Introduction}

Wua-Wua Subdistrict is one of the sub-districts in Kendari City, Southeast Sulawesi, Indonesia and is an existing area for agricultural, plantation and livestock commodity 
development centers. In addition to topographical conditions, the climate is also very supportive of this area for the development of various agricultural and livestock commodities. The livestocks include chickens, ducks, goats, and cows, while the food crops are corn, cassava, sweet potatoes, fruits such as bananas, rambutans, oranges, durian, vegetables like eggplant, tomatoes, moringa, spinach, and other vegetables.

Such a condition can be utilized to improve community independence based on the potential, expertise and strong will of the community itself, so it is necessary to form forms of empowerment activities through training to hone the ability of each community to start the desired business field. In general, community empowerment is one of the pillars in supporting and strengthening economic income both individually, in community groups and in a region. The essence of empowerment activities that aim to bring about change for the better is related to the addition of knowledge and skills that can add value to health and economic aspects in the era of the Covid-19 pandemic. In other words, empowerment must be designed as a learning process through training activities [1].

In the field of animal husbandry, so many commodities and livestock food ingredients can be used as a source of inspiration and motivation in community empowerment activities. Especially for meat commodities, there are many advantages because processed meat products are very popular and become a delicious meal at various events. Meat can be obtained from the slaughter of large animals such as cows, buffaloes and goats or poultry [2] [3] [4] [5].

Meatballs are one of the most popular processed meat products by the public and are rich in nutrients which are often classified into food sources of protein, because they contain high protein levels [6] [7] [8]. Meatballs are very popular with the community because they are not expensive, nutrient dense and can be found around settlements [9] [10]. Protein functions to increase the body's immune system, forming antibodies that are useful for preventing the body from developing infectious diseases such as covid-19. Currently meatballs have a number of variations from the original one including by adding vegetables.

One of the ingredients that can be added in making meatballs is Moringa leaves. Moringa leaves can be processed into powder form which can be used as food fortification [11]. Moringa leaves contain lots of protein, vitamins and minerals. With the addition of Moringa leaves, besides being able to increase the nutritional value of meatballs, it also produces a more economical product because Moringa leaves are 
cheap and easy to obtain. A study reported that Moringa leaves contain 3 times the protein content of egg protein, 25 times iron and 3 times the vitamin $\mathrm{C}$ spinach, 12 times the calcium and 2 times the milk protein [12].

\section{Method}

\subsection{Problem analysis}

Based on the results of field observations made in the Wua-Wua District community there are a number of main issues that are prioritized to be addressed:

a. Lack of understanding of PKK groups about food produced by livestock that stimulates immunity.

b. People do not know about functional food.

c. The public does not yet know how to process livestock food that is good so it produces products that have functional properties that are good for health.

\subsection{Solution}

Related to the proposed problem solving above, the right solution is:

a. Conducting learning in the form of theory and demonstration / training and counseling about food produced by livestock stimulating immunity.

b. Providing guidebooks, leafleats, and assistance to the public about the preparation of ingredients and the manufacture of functional food products (herbal meatballs).

c. Provide stimulation so that people are willing and able to increase creativity / skills in making livestock food products that are beneficial to health and can increase community income.

\subsection{Result and Discussion}

The community benefits from this pengididian activities by linking knowledge and technology for processing livestock products. The benefits are in the form of direct product manufacturing training. This dedication training aims to make the community directly understand the ingredients and techniques of making herbal meatball products.
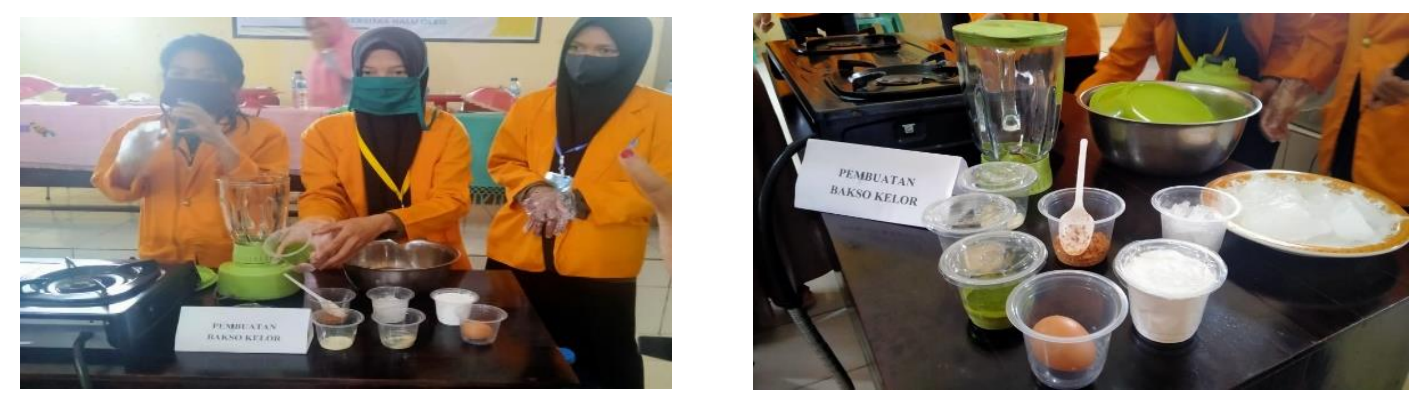

Figure 1. Training on making herbal meatball products Figure 2. Ingredients used to make herbal meatballs 


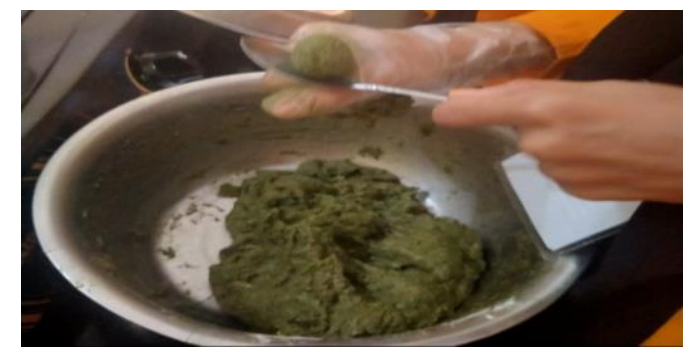

Figure 3. The process of printing herbal meatballs

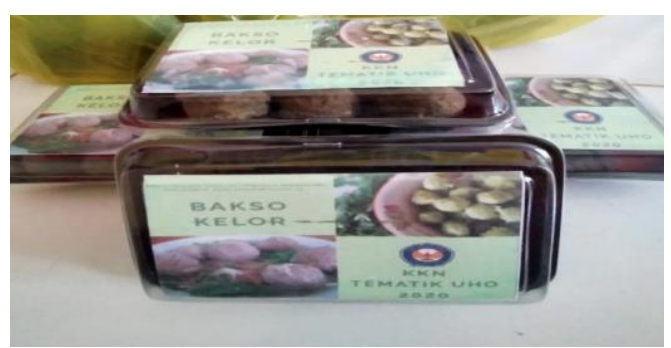

Figure 4. Packaging of herbal meatball products

This training is also aimed at making the community able to apply these products not only for consumption but also to help them create a home industry for products that have many health benefits.

3. Consumption level of processed meat products namely meatballs in the people of Wua Wua District

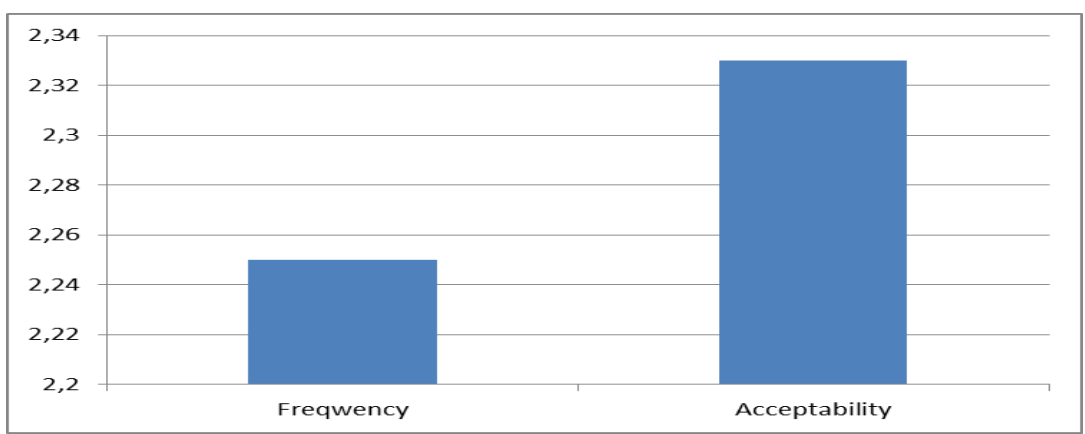

Figure 5. General results of organoletic test for herbal meatballs in the community to Wua Wua District

The level of consumption of the people of Wua Wua Subdistrict on processed meat products from meatballs in terms of the frequency of consumption is seen, which is not often (sometimes a cage). Processed products for livestock with the main ingredients of meat prices in the market are quite high, so for daily consumption can not yet. Meatball consumption in general is only as a condensed consumption which cannot be the main consumption yet.

Meatball food products in terms of the level of community preference Wua Wua District they really like meatballs. Society in general is very fond of processed meat, one of which is meatballs. 
3. Organoleptic Products of herbal meatball food products to the people of Wua Wua

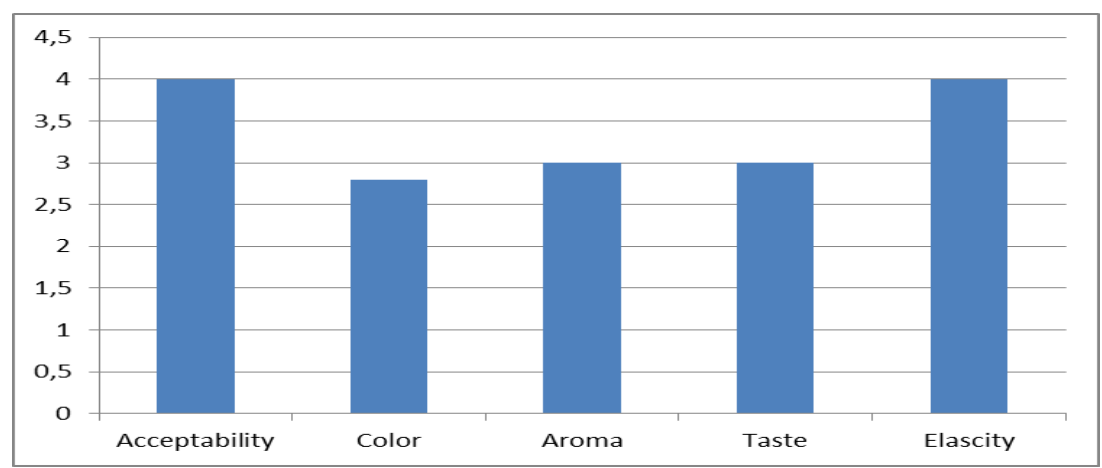

Figure 6. General results of organoletic test for herbal meatballs in the community to Wua Wua District

\section{Color}

The color of the herbal meatballs is rather green due to the addition of Moringa leaf flour. The addition of moringa leaf flour can change the pigment of beef meatballs when mixing where beef when processed into meatballs turn gray because of the binding of tapioca flour with beef after the addition of Moringa leaf flour affects the color of the meatballs to be rather green. The green color of the herbal meatballs is influenced by the green color of Moringa leaves, namely chlorophyll. According to [14] that Moringa contains green pigment which is often called chlorophyll. According to Winarno [15] chlorophyll is a green pigment contained in chloroplasm together with carotein and xanthophyll.

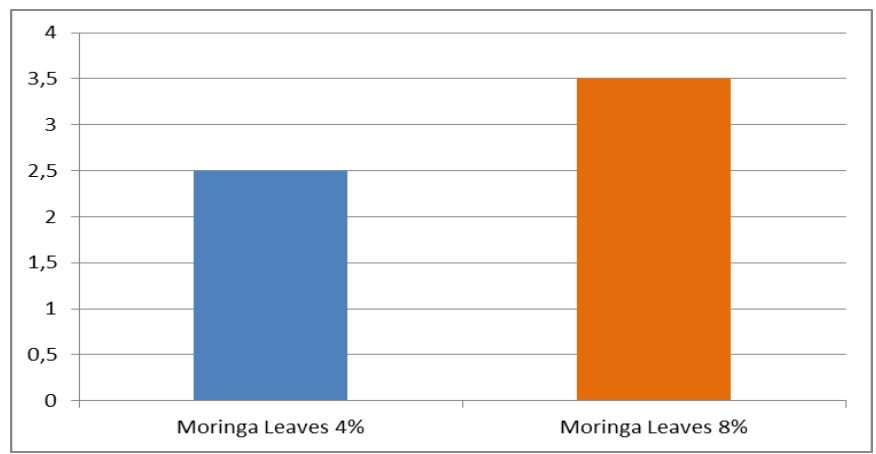

Figure 7. Graphic score of herbal meatball color

The aroma of the meatballs added to the moringa leaf flour has the aroma of Moringa but does not cover the distinctive aroma of the meat. The aroma of the moringa according to [16] that the leaves of Moringa has a distinctive aroma. The scent of langu on Moringa leaves according to [12] explains that the addition of Moringa affects the aroma caused by Moringa leaves containing the enzyme lipoxidee, an enzyme found in green vegetables because the lipoxide enzyme hydrolyzes fat into compounds that cause 
odor which is classified as hexanal 7 and hexanol. The aroma of Moringa in the herbal meatballs is still accepted by the people when consuming the herbal meatballs.

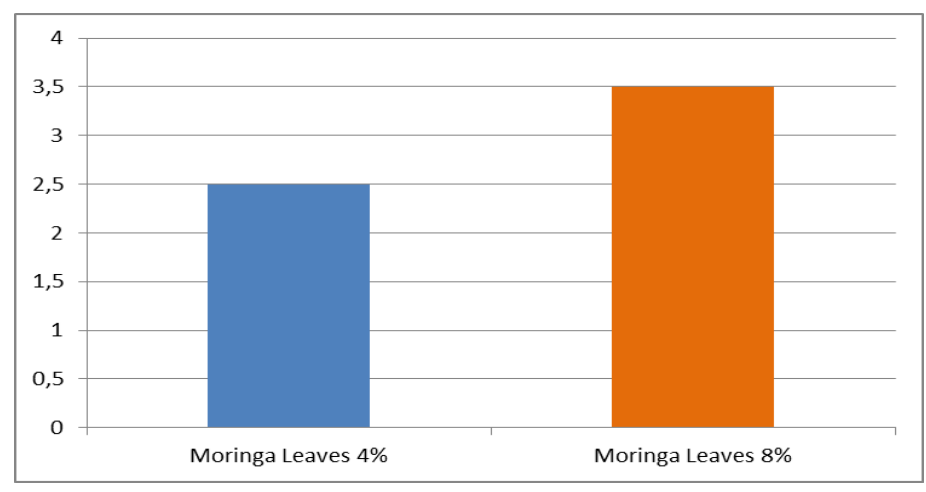

Figure 8. Graphic score of aroma of herbal meatballs

\section{Taste}

The taste of herbal meatballs with the addition of Moringa leaf flour tastes a little moringa. The taste of Moringa is a little sepat but does not cover the distinctive taste of meatballs because of the addition of seasonings and flavorings. The cause of bitter or shoe on Moringa leaves is tannin compounds. Herbal meatball products according to the community taste is still accepted by the sense of taste [17].

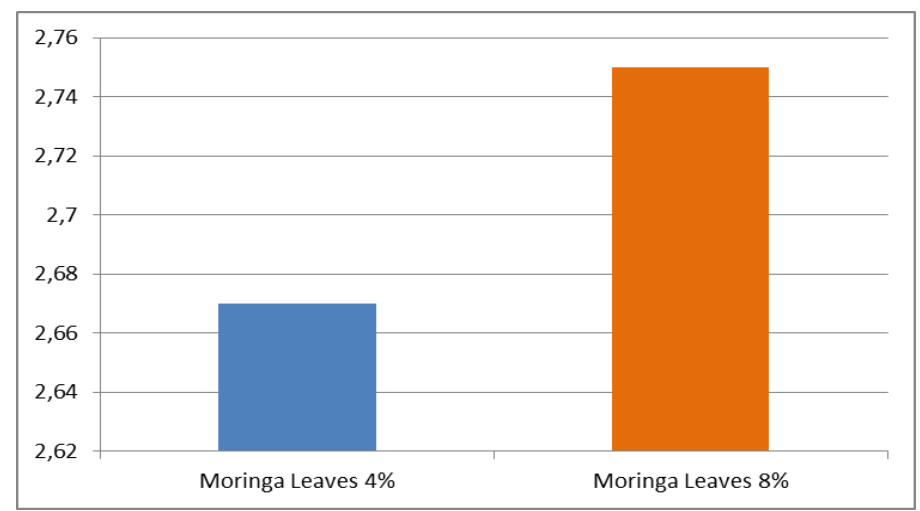

Figure 9. Graphic score of herbal meatball color

\section{Elasticity}

Some livestock products are desired which are chewy or elastic and are not easily destroyed by chewing. Because during the chewing activity the savory and delicious taste of the product will be felt and enjoyed before being swallowed. In meatball products, the elasticity of the product is an indicator of product quality. The elasticity of the herbal meatballs is caused by the fresh meat ingredients used and the addition of tapioca flour as a binding agent and moringa leaf flour. A plasticity score on the herbal meatballs made during the training is presented in Figure 10. 


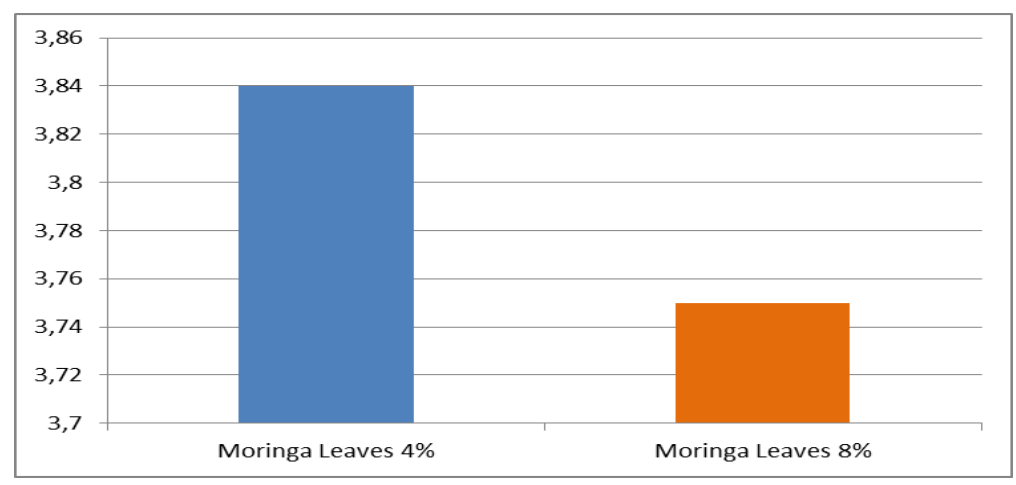

Figure 10. Graphic score of the elasticity of herbal meatballs

\section{Preference}

Likeability or liking is an indicator of acceptance of a product as a final conclusion after a panelist or consumer observes whether to follow up by accepting the product, buying and recommending it to other parties or rejecting it. Based on the results of the training activities, the public has a high acceptance of herbal meatballs with high acceptance of livestock food products with a blend of herbal ingredients. This is because meatballs are generally their favorite food and have been provided with material on the benefits of herbal ingredients to increase endurance during a pandemic.

Providing training materials related to the Covid 19 virus, the dangers and modes of transmission as well as prevention efforts with health protocols and consuming natural healthy foods to strengthen body conditions such as herbs greatly motivated the participants.

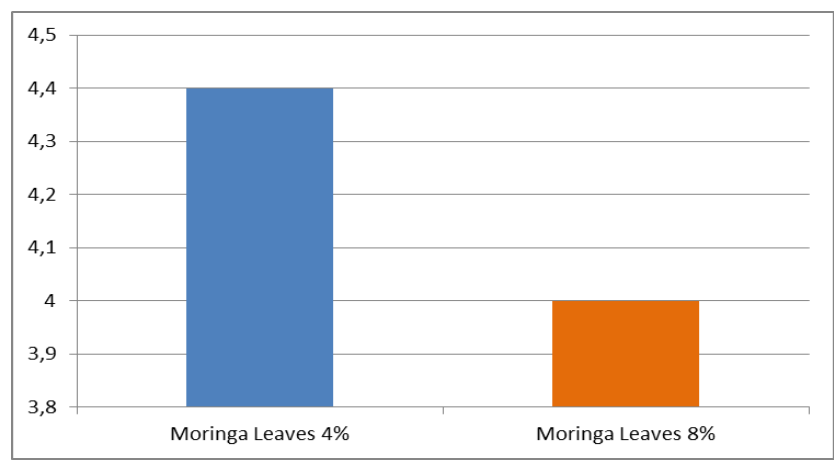

Figure 11. Graphic score preference for herbal meatballs

\section{Conclusion}

It was concluded that community service activities regarding the application of herbal meatball processing technology to improve tubular stamina during the pvidemic covid 19 period had provided additional knowledge and skills to the people of Wua Wua Subdistrict, Kendari City. The community participating in the activity has applied herbal meatball processing technology to increase stamina against the covid pandemic 
19 because the raw material of Moringa leaves is widely planted by the people of Kendari as a type of staple vegetable.

\section{Acknowledgments}

We express our thanks to the Chancellor of Halu Oleo University and Chair of the Institute for Research and Community Services who have funded the Implementation of the Integrated Community Service Program Thematic Work Counseling (KKN) of the 19th Covid Countermeasure of Halu Oleo University 2020, through DIPA funds of Halu Oleo University Budget Year 2020 with Work Implementation Agreement Letter Number: 770F / UN29.20 / AM / 2020. Thank you to the Head of Wua Wua Sub-District, Anawai Sub-District Head, Bonggoeya Sub-District Head, Mataiwoi Sub-District Head and Wua Wua Sub-District Head and staff for your good reception, as well as all UHO Thematic KKN 2020 students and all parties who cannot be mentioned one by one, for their assistance during the activity so that they can walk smoothly.

\section{References}

[1] Mardikanto T and Soebiato P, "Community development". Bandung, Alfabeta. 2013.

[2] Nuraini, I. Armila, H. Hafid, S.H., Ananda. "Quality of chicken meat which is given treatment of electric stimulation". Journal of Physics: Conference Series. 1364: 012 - 072, 2019.

[3] Hafid H, A Napirah, L Meliana, Nuraini, Inderawati. "Organoleptic characteristic of frozen beef on different thawing methods". Proceeding ADRI International Multidisciplinary Conference 10th, Batam 1, 231-233, 2017.

[4] Hafid H., A. Napirah, Fitrianingsih, and A. Efendi, "Organoleptic Characteristics of Chicken Meatballs that Using Gelatin as a Gelling Agent”. IOP Conf. Series: Earth and Environmental Science 465 012013, 2020.

[5] Patriani P, H Hafid, E Mirwandhono, and T H Wahyuni. "Effect of kluwak biomass fermentation and storage time on meat quality". IOP Conf. Series: Earth and Environmental Science 460 012003, 2020.

[6] Nullah, L. N. H. Hafid, and A. Indi. "The effect of local filler material on the physical and chemical quality of laying hens meatballs". JITRO 3 (2): 58-63, 2016.

[7] Hafid. H. "Consumer acceptance of beef meatballs from different ingredients of meat and flour". Buletin Penelitian Sosek. 15 (8) : 89-95, 2005.

[8] Hafid, H. "Introduction to Meat Processing: Theory and Practice". First printing. Alfabeta Publisher. Bandung, 2017.

[9] Rosita, F. H. Hafid, and R. Aka. "Cooking losses and organoleptic qualities of beef meatballs with the addition of sago flour to different levels". JITRO 2 (1): 14-20, 2015. 
[10] Yusuf A, H Hafid, AM Tasse. "Analysis of income of meatballs traders in Kolaka Regency". Journal of Science and Technology of Tropical Animal Husbandry 1 (4), 57-66, 2016.

[11] Aminah, S., Tezar R., dan Muflihani Y. "Nutrient content and functional properties of Moringa oleifera. Urban Agriculture Bulletin”. 5 (2): 35-44, 2015.

[12] Diantoro A, Rohman, M., Budiarti, R., and Palupi H. T. "Effect of Addition of Moringa oliefera L. Extract on the quality of Yogurt". Journal of Food Technology. 6(2): 59-66, 2015.

[13] Hafid H., Nuraini, Inderawati, S.H. Ananda. "Strengthening student skills through training in making meatballs with culled chicken meat". Journal of Saintech Transfer (JST) Vol. II, No. 1, 2019 : 74-83, 2019.

[14] Khasana, V. and Pudji A. "Effect of the addition of Moringa Oleifera leaf extracts on the sensory quality and protein content of noodle vasah substitution mocaf flour". Journal of Engineering Competencies. Vol 11, No. 2, 2019.

[15] Winarno, F.G. "Food and Nutrition”. PT Gramedia Pustaka Utama,Jakarta, 2004.

[16] Roihanah, M. "The Influence of the Amount of Keragenan and Pandanwangi (Pandanus Amarylifous) Leaf Extract on the Organoleptic Properties of Moringa Oliefera Drink". Journal of Catering, 3(3), 2014.

[17] Rosyida, A. Z. and Rita, I. "Study of respondents' preference level for side dishes from diversifying side dishes from Moringa oleivera leaves". Journal of Catering. 5(1), 2015. 